\title{
Assessment of the possibility of implementing the product identification algorithm on the example of a production and service company
}

\author{
Mariusz Niekurzak (D)
}

AGH University of Science and Technology, Faculty of Management, Krakow

\begin{abstract}
This article discusses a prototype of a programme that functions to identify the flow of products in a production or service company. This application allows you to verify the operation of the system based on barcodes and assess the return on investment. For companies operating in the field of electroplating coatings, tools were designed to manage the customer base, details, and orders. As well as to track the flow of customer products in internal logistics. The coding method, labels, and appropriate research and measurement equipment have been selected. Moreover, the results of the prototype implementation and the benefits of introducing this technology to the enterprise have also been described.
\end{abstract}

Keywords: barcodes, standardization, label, logistics

OCENA MOŻLIWOŚCI WDROŻENIA ALGORYTMU IDENTYFIKACJI PRODUKTU NA PRZYKŁADZIE FIRMY PRODUKCYJNO-USŁUGOWEJ

Streszczenie: W artykule omówiono prototyp funkcjonowania programu przeznaczonego do identyfikacji przepływu wyrobów w przedsiębiorstwie produkcyjno-usługowym. Aplikacja ta umożliwia weryfikację działania systemu opartego na kodach kreskowych i ocenę zasadności inwestycji. Dla analizowanego przedsiębiorstwa, działającego w branży powłok galwanicznych, zaprojektowano narzędzia umożliwiające zarządzanie bazą klientów, detali i zleceń oraz śledzenie przepływem wyrobów klienta w logistyce wewnętrznej. Dobrany został sposób kodowania, etykiety oraz odpowiednia aparatura badawczo-pomiarowa. Ponadto opisano wyniki wdrożenia prototypu oraz korzyści płynące z wprowadzenia danej technologii do przedsiębiorstwa.

Słowa kluczowe: kody kreskowe, standaryzacja, etykieta, logistyka

https://doi.org/10.7494/978-83-66727-47-2_9 


\section{Introduction}

The current increase in the number of goods on the market, changes in assortment, the emergence of new types of goods, and the general need of the consumer to access information. All of that necessitates evolutionary changes in the methods of identification and information flow about goods and services. The importance of using computer technologies and, consequently, optimizing solutions in the field of automatic identification and storage of ADC (Automatic Data Capture) or Auto ID (Automatic Identification) has grown (Dębowski 2006). ADC systems make it possible to collect and enter data directly into the IT system database without the use of a keyboard. Current tools used for automatic identification e.g., the following tools: optical (barcodes), magnetic (magnetic tape), electromagnetic (radio waves), biometric (voice recognition). Bar codes belong to the most common group of automatic identification methods, which were initially developed in the trade of goods. However, to improve customer service, cash registers with scanners for reading barcodes placed on goods were introduced. The use of cash registers contributed to shortening the time of activity, and reducing the probability of making mistakes compared to traditional methods. This allows for optimizing the functioning of the organization and more efficient customer service (Długosz 2009).

Many economists agree that the identification of goods affects various parts of the economy, such as: faster and almost error-free identification of inventory records, quick access to information, tracking current inventory levels or the flow of goods between contractors, and facilitating inventory. The initiation of barcode marking of goods has made them a convenient identification tool. They are constantly being improved and the types of codes are evolving. The new codes have replaced the old faulty ones, introducing solutions that take into account the needs of consumers and guarantee greater efficiency of the identification activities. This development is dictated by the development of computer and telecommunications technologies, which, together with the coding theory, are intended to improve automatic identification. In Poland, the most famous codes are the EAN-8 and EAN-13 barcodes placed on unit packages (Kwaśniowski and Zając 2004). These codes are used in retail checkout systems. The main tasks of marking goods on codes are to facilitate the recording of product movements in trade, regardless of the country of their origin. Generating code allows for the recognition of a given object, which may be a product, machine, device, person, or document through a computer system without or with minimal human involvement. The bar code in general can be called the graphic representation of certain characters by combinations of dark and light elements (in this case, dashes), established by the 
above-mentioned norms and rules. The use of barcodes in organization's activities brings measurable benefits like: increasing the quality of the processes of transmitting information about demand and inventory, greater data reliability, saving manpower, improving the mutual relations between trade and production, and the possibility of obtaining precise information. For e.g. on the location of materials in the warehouse acceleration of processes by eliminating many errors, losses and the amount of time spent on correcting errors that arose when entering data on receipts, warehouse transfers and production notifications using traditional methods (Hałas 2012).

Literature (Śląski and Giga 2005, Radziejowska 2012, Łazicki et al. 2016, Urban et al. 2018) contains a lot of items on logistics management in a production company and the use of new technologies in the operation of production and warehouse processes. However, a significant number of researchers ignore the topic of implementing new technologies in their practical application within the enterprise and the integration of individual technologies with IT systems. With this in mind, the aim of the article is to identify areas of time and cost wastage in the process of marking and shipping goods and to indicate the possibility of applying technological innovation regarding these processes. The changes include replacing the traditional method of marking collective packages with barcodes with the automatic identification method. This method will shorten the time needed to identify goods and eliminate errors.

\section{Research program}

The research was divided into several stages, of which initially it was necessary to: recognize the course of the internal logistics and warehousing process of a given company, define the scope of the system, collect information on current problems, define the goals, limitations, available equipment, and requirements related to the existing Quality Management System according to PN-EN ISO 9001, learn the nomenclature in circulation. The next steps are (Fox 2021):

- System testing by checking the existing IT solutions, talking to employees, getting the number of customers and details in the database, creating data and product flow graphs.

- Analysis of the system user needs and specifying what information they really need.

- Transforming the project into a solution proposal along with recommended changes in the company and consultation with a group of people who will be future users. Introducing corrections, checking the project in terms of initially defined tasks. 
- Building a system based on the company's requirements, with possible consultation on previously unforeseen elements. At this stage, it will be necessary to select codes, design logistics labels, create a database, a program that allows data processing and display, and to program barcode scanners to record changes in the location of logistics units and connect them with other elements of the part information system.

- Carrying out a project test on test data that does not interfere with the actual data in the company, with the participation of system users and taking into account the most complicated cases.

- Presentation of analysis of the obtained results to the company's management board and a decision to invest in a professional system, fully integrated with ERP.

\section{Description of the original condition of the analyzed enterprise}

The company is a Polish company providing electroplating services. The basic coatings offered are: zinc, zinc-nickel, iron-zinc, copper, copper-nickel, copper-nickel-brass, brass, silver, tin, decorative chrome. The company has one production plant with a reception warehouse, six production lines, and a warehouse for finished products. The company provides most of its services to manufacturers in the automotive market and the energy industry.

The company joined the system implementation programme to improve the information flow process in the plant. Initially, only information about the delivery or release of the customer's goods was available from the GRN and WZ documents entered into the ERP system. However, the flow of products was not tracked throughout. The location of a given container was not monitored in IT terms, therefore it was necessary to physically check its place and progress in the process. Additionally, container labels were created by each time entering data into an Excel table and printing it. Also, the previously printed blank labels were refilled manually. Both methods generated mistakes when typing long alphanumeric names of client details. Moreover, the company did not have any readers, terminals, or specialized label printers in stock. A laser printer was available for use in the Reception Warehouse. The PN-EN ISO 9001 Quality Management System applicable at the plant required the title of the Product Identification Card, the number $\mathrm{F} / 07 / 04$, and the information about the revision number and the last update on the label. The map of the customer's product flow is shown in Figure 1.

The following names were adopted in the research: Customers, Details, Orders, Containers, Reception Warehouse, Pre-production Warehouse, Production, Finished Goods Warehouse. The abbreviations KJ - Quality Control Department, SM - Warehouse, IZ - logistic unit content identifier will also be used. 


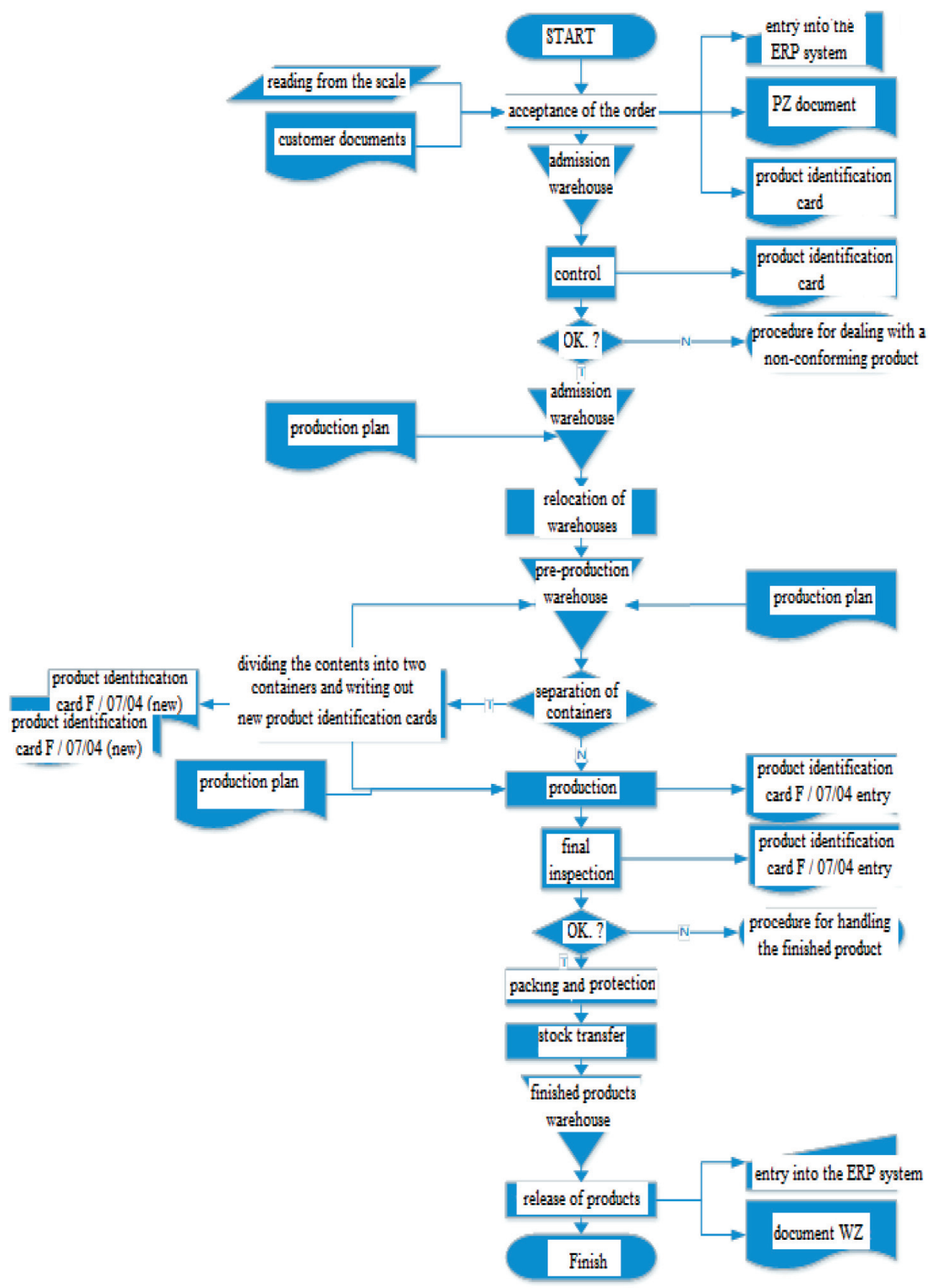

Fig. 1. Map of the customer's product flow

Source: own study based on GALWAH (n.d.) 
The company currently has over 30,000 different customer details in its database. This information is important to select the appropriate number of service identification codes based on these details.

\section{Principles of code and label selection in the logistic flow of products}

The label and code selection depends on the content and the logistics unit. In this case, the logistics unit was non-standard and also non-uniform in content. This was due to the fact that the goods were delivered to different customers, in different packages with a different number of details. In addition, there were cases when the client needed an urgent service, for example, 1.5 containers, which caused the content of logistic units to be separated. Due to the separation, the code has to show what and in what amount is being distributed. Moreover, according to the standard, each logistics unit must be marked with an SSCC number, which is the only mandatory element. On this basis, it was decided to use the data strings contained in Table 1.

Table 1

Used IZ

\begin{tabular}{|c|c|c|c|c|}
\hline IZ & $\begin{array}{c}\text { The full title of the application } \\
\text { identifier }\end{array}$ & Format & $\begin{array}{c}\text { English data } \\
\text { designation }\end{array}$ & $\begin{array}{c}\text { Polish data } \\
\text { designation }\end{array}$ \\
\hline 00 & Logistic Unit Serial Number & $\mathrm{n} 2+\mathrm{n} 18$ & \multicolumn{2}{|c|}{ SSCC } \\
\hline 01 & Global Trade Item Number & $\mathrm{n} 2+\mathrm{n} 14$ & \multicolumn{2}{|c|}{ GTIN } \\
\hline 10 & Lot or batch number & $\mathrm{n} 2+\mathrm{an} . . .20$ & BATCH/ LOT & SERIES \\
\hline
\end{tabular}

Source: own study based on GALWAH (n.d.)

Some IZ have mandatory links to other information that must be jointly contained in the code. For the analyzed cases, their requirements are presented (Tab. 2).

Table 2

The relationship between IZ

\begin{tabular}{|c|c|c|c|}
\hline IZ & Description & $\begin{array}{c}\text { Mandatory } \\
\text { connection with: }\end{array}$ & Explanation \\
\hline $\begin{array}{c}01 \text { (GTIN) of } \\
\text { N1 =9 }\end{array}$ & $\begin{array}{c}\text { Variable measure trade } \\
\text { item identifier }\end{array}$ & $\begin{array}{c}30,3 \mathrm{nnn}^{1}, 3 \mathrm{nnn}^{2} \text { or } \\
8001\end{array}$ & Variable quantity information \\
\hline 10 & $\begin{array}{c}\text { Production batch } \\
\text { number }\end{array}$ & 01 or 02 & $\begin{array}{c}\text { GTIN or identifier of the } \\
\text { contents of a logistic unit }\end{array}$ \\
\hline
\end{tabular}

$3 \mathrm{nnn}^{1}$, where the first three digits are $312,313,324,325,326,327,328$, and 329.

$3 \mathrm{nnn}^{2}$, where the first three digits are $310,311,314,315,316,320,321,322,323,350,351,352$, $356,357,360,361,364,365$, and 366 .

Source: own study based on GALWAH (n.d.) 
In view of the above requirements, it was found that in addition to the previously selected identifiers 00,01 , and 10 , it is necessary to use information about a variable number:

- 30 - variable number (pieces),

- $3 n n n^{1}$ - trade measures that cannot be added together,

- $3 n n n^{2}$ - trade measures that can be added together,

- 8001 - variable values of products in rolls.

It was decided to use these data with which it will be possible to present the number of details in pieces or kilograms. The structure and designation of the adopted FIs with information on a variable number are presented in Table 3.

Table 3

Construction and designation of the adopted IZ with information on a variable quantity

\begin{tabular}{|c|c|c|c|c|}
\hline IZ & $\begin{array}{c}\text { The full title of the } \\
\text { Application Identifier }\end{array}$ & $\begin{array}{c}\text { Data } \\
\text { format }\end{array}$ & $\begin{array}{c}\text { English data } \\
\text { designation }\end{array}$ & $\begin{array}{c}\text { Polish data } \\
\text { designation }\end{array}$ \\
\hline 30 & a variable number & $\mathrm{n} 2+\mathrm{n} . . .8$ & VAR. COUNT & $\begin{array}{c}\text { variable } \\
\text { quantity }\end{array}$ \\
\hline $310(\mathrm{n})$ & net weight & $\mathrm{n} 6$ & $\begin{array}{c}\text { NET WEIGHT } \\
{[\mathrm{kg}]}\end{array}$ & net weight $[\mathrm{kg}]$ \\
\hline
\end{tabular}

Source: own study based on GALWAH (n.d.)

The value of the last character " $n$ " for IZ 310 (n) indicates the position of the decimal point. If it is 0 , the weight is given with an accuracy of $1 \mathrm{~kg}$, for 9 , the weight represents the data in micrograms, i.e., $0.000000001 \mathrm{~kg}$. In the prototype of the system, it was decided to use $\mathrm{n}=2$.

\section{Identification of the logistic unit}

Serial Shipping Container Code SSCC - The Serial Logistic Unit Number is used by companies to identify logistics units that may contain any combination of transaction items, packed together for storage and/or transport purposes, such as a container or a pallet. The SSCC is crucial for tracking the flow of logistics units as it uniquely identifies them. This enables the effective management of orders and transport (GS1 2021). The SSCC can be a barcode or EPC/RFI radio tag encoded while ensuring accuracy and ease of identification when moving between trading partners anywhere in the world. SSCC codes can also be made available electronically to customers, which allows them to check information about the shipment status. 
Its associated Application Identifier is 00. The structure of the Logistic Unit Serial Number is shown in Table 4.

Table 4

Construction of SSCC

\begin{tabular}{|c|c|c|c|c|c|}
\hline \multirow{3}{*}{ IZ } & \multicolumn{5}{|c|}{$\mathrm{SSCC}$} \\
\hline & \multirow{2}{*}{$\begin{array}{l}\text { Extension } \\
\text { character }\end{array}$} & \multicolumn{2}{|c|}{ Company prefix GS1 } & \multirow[b]{2}{*}{ Unit designation } & \multirow[b]{2}{*}{ Check digit } \\
\hline & & $\begin{array}{c}\text { National } \\
\text { organization } \\
\text { prefix GS1 }\end{array}$ & $\begin{array}{l}\text { Coding unit } \\
\text { number }\end{array}$ & & \\
\hline 00 & $\mathrm{~N}_{1}$ & $\mathrm{~N}_{2} \mathrm{~N}_{3} \mathrm{~N}_{4}$ & $\begin{array}{c}\text { to } \\
\mathrm{N}_{5} \mathrm{~N}_{6} \mathrm{~N}_{7} \mathrm{~N}_{8} \\
\text { from } \\
\mathrm{N}_{5} \mathrm{~N}_{6} \mathrm{~N}_{7} \mathrm{~N}_{8} \mathrm{~N}_{9} \\
\mathrm{~N}_{10} \mathrm{~N}_{11}\end{array}$ & $\begin{array}{c}\text { to } \\
\mathrm{N}_{9} \ldots \mathrm{N}_{17} \\
\text { from } \\
\mathrm{N}_{12} \ldots \mathrm{N}_{17}\end{array}$ & $\mathrm{~N}_{18}$ \\
\hline
\end{tabular}

In this system prototype, it was assumed:

\begin{tabular}{|l|l|l|l|l|l|}
\hline 00 & 1 & 590 & 1234 & $\begin{array}{l}\text { NNNNN } \\
\text { NNNN }\end{array}$ & N $_{18}$ \\
\hline
\end{tabular}

Source: own study based on GALWAH (n.d.)

The SSCC number is the only mandatory element of each logistic label. If all available SSCC numbers for a given company are used up, the numbering starts from the beginning. This is due to the long period of time between the first logistics unit and the one marked with the last available SSCC number.

\section{Identification of the goods}

Global Trade Item Number (GTIN) is used to uniquely identify trade items (products and services) around the world. It comes in four structures that can be represented in the form of a barcode: GTIN-8, GTIN-12, GTIN-13 and GTIN-14. The choice of structure type depends on the type of goods and the application (Nelson 1997). The most commonly used is GTIN-13, which is equivalent to EAN-13 in retail. In this case, however, it will be necessary to use GTIN-14 due to non-retail use.

Non-retail units of different quantities require a measure of their content. That is what the GTIN-14 is for with the index digit "9" in the first position. It is a mandatory part of the Variable Measure Trade Item Number. It also indicates that supplementary information related to the measure or quantity will be included.

The GTIN-14 consists of 14 characters, including: Indicator Digit "9", Company GS1 Prefix, Item Reference Number and Check Digit (calculated from Item Number). 
Its assigned Application Identifier is 01. The structure of the Global Trade Item Number is shown in Table 5 .

Table 5

Construction of GTIN-14

\begin{tabular}{|c|c|c|c|c|c|}
\hline \multirow{3}{*}{ IZ } & \multicolumn{5}{|c|}{ GTIN-14 } \\
\hline & \multirow{2}{*}{ Indicator } & \multicolumn{2}{|c|}{ GS1 company prefix } & \multirow{2}{*}{$\begin{array}{l}\text { Designation of the } \\
\text { product unit }\end{array}$} & \multirow{2}{*}{$\begin{array}{c}\text { Check } \\
\text { digit }\end{array}$} \\
\hline & & $\begin{array}{c}\text { National organization } \\
\text { prefix GS1 }\end{array}$ & $\begin{array}{l}\text { Coding unit } \\
\text { number }\end{array}$ & & \\
\hline 01 & 9 & $\mathrm{~N}_{2} \mathrm{~N}_{3} \mathrm{~N}_{4}$ & $\begin{array}{c}\text { to } \\
\mathrm{N}_{5} \mathrm{~N}_{6} \mathrm{~N}_{7} \mathrm{~N}_{8} \\
\text { from } \\
\mathrm{N}_{5} \mathrm{~N}_{6} \mathrm{~N}_{7} \mathrm{~N}_{8} \mathrm{~N}_{9} \\
\mathrm{~N}_{10} \mathrm{~N}_{11}\end{array}$ & $\begin{array}{c}\text { to } \\
\mathrm{N}_{9} \mathrm{~N}_{10} \mathrm{~N}_{11} \mathrm{~N}_{12} \mathrm{~N}_{13} \\
\text { from } \\
\mathrm{N}_{12} \mathrm{~N}_{13}\end{array}$ & $\mathrm{~N}_{14}$ \\
\hline
\end{tabular}

In this system prototype, it was assumed:

\begin{tabular}{|c|c|c|c|c|c|}
\hline 01 & 9 & 590 & 1234 & NNNNN & $\mathrm{N}_{14}$ \\
\hline
\end{tabular}

The Coding Unit Number is 4 to 7 digits long, which, together with the GS1 National Organization Prefix, completes the identifier assigned to each system user. It depends on the company's needs, and in Poland it is from 7 to 10 digits. The unit designation has 2 to 5 digits that should be posted in sequence.

The last element is the check digit, which is calculated from all others according to the GS1 algorithm to verify that the scanned barcode is correct.

In the described case study, 5 characters are required for product units, because currently there are 30,000 in the company's database product details. Therefore, the coding unit number must be four-digit long.

\section{Identification of a batch or production batch}

The Application Identifier 10, for example, defines the lot or batch number of the unit on which it is placed or its contents. This number is to be associated with information that the manufacturer deems essential to identify a trade item with specific characteristics. This is necessary, for example, in the recall process (PN-ISO/IEC 15420:2007). It could actually be a production batch, number, change, or an internal production code, as long as this data allows for trade item tracking. This number is the only attribute of a specific unit, which must be specified, including the GTIN or logistic unit content identifier - IZ 02 in the barcode. The structure of the Application Identifier 10 is shown in Table 6. 
Table 6

Construction of IZ 10

\begin{tabular}{|c|c|}
\hline IZ & Designation of the production series \\
\hline 10 & from $\mathrm{N}_{1}$ \\
& to $\mathrm{N}_{1} \mathrm{~N}_{2} \mathrm{~N}_{3} \mathrm{~N}_{4} \mathrm{~N}_{5} \mathrm{~N}_{6} \mathrm{~N}_{7} \mathrm{~N}_{8}$ \\
\hline
\end{tabular}

Source: own study based on GALWAH (n.d.)

\section{Label structure}

The logistics label is the basic tool for marking and monitoring the flow of transport units. Its purpose is to provide complete information about the load on which it is placed in both visually and machine-readable form. It also enables identification throughout the entire supply chain. It is used for all types of shipping, units in logistics and transport applications. The label standard was developed by GS1 in cooperation with manufacturers, carriers, and retailers. The label structure is divided in three groups (Śliwczyński et al. 2013, Żyła 2021):

1) upper part - any inscriptions and graphic symbols,

2) middle part - text interpretation of data contained in the code,

3) lower part - bar code.

Data in a standardized form is clear to all GS1 system participants. Based on the requirements of the standard, the adopted Application Identifiers, and additional company requirements, the label shown in Figure 2 was designed.

\begin{tabular}{|c|c|c|c|c|}
\hline \multirow{3}{*}{ 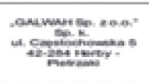 } & \multirow{3}{*}{\multicolumn{2}{|c|}{$\begin{array}{l}\text { Product identification } \\
\text { card }\end{array}$}} & \multicolumn{2}{|c|}{ Forrout } \\
\hline & & & $=$ & $=$ \\
\hline & & & 02 & 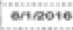 \\
\hline \multicolumn{5}{|c|}{ Date of acceptance of the delivery inspection } \\
\hline \multicolumn{3}{|c|}{ Final inspection date } & \multicolumn{2}{|c|}{ Signature } \\
\hline \multicolumn{5}{|c|}{ Protocol certificate number and date } \\
\hline \multicolumn{5}{|c|}{ 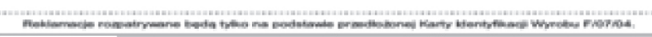 } \\
\hline Customer & Customer & \multicolumn{3}{|c|}{ internal client index } \\
\hline \multirow{2}{*}{\multicolumn{2}{|c|}{ Customer detail name }} & \multicolumn{3}{|c|}{ otian } \\
\hline & & \\
\hline \multicolumn{2}{|c|}{ Shell } & sum & & \\
\hline \multicolumn{2}{|c|}{ net quantity / weight } & setres & & \\
\hline & & & & \\
\hline
\end{tabular}

Fig. 2. Sample label

Source: own study based on GALWAH (b.d.)

The structure has been divided into 3 segments. The upper, non-standard part has been additionally divided with a dashed line for a better readability. This part is to be 
used during quality control. Date and controller stamps are used in these fields. This identifies the checked products visually. The middle segment has the necessary information identifying the container and its contents as well as information for the operator, e.g., about the coating and its thickness. The last part is, according to the standard, the bar code field. The whole label was generated from a web application in the form of a PDF file, which can be easily printed and placed on a suitable container.

\section{Location codes - GLN}

Global Location Number (GLN) is the number used to uniquely identify (Majewski 2006):

- physical locations, while allowing the freedom to choose the type and level of detail. it is assigned to a permanent geographical address;

- digital locations, i.e., electronic addresses, are used for communication between computer systems; this applies to the exchange of data on transactions between systems, e.g., delivery of an account to the accounting system;

- legal persons, i.e., enterprises, government units, charitable organizations, individual units, and institutions that have the legal capacity to conclude contracts and contracts;

- functions - departments in the company that perform a specific function in the business process.

The GLN is encoded as a GS1-128 barcode with an Application Identifier (414) or as a radio EPC / RFID allowing automatic identification. It may also be used with other Application Identifiers that stand for "Deliver To:", "Receipt For:". The code consists of a GS1 Company Prefix, a Location Reference Number, and a Check Digit. It is 13 characters in total. The check digit is determined in accordance with the rules for GTIN-13. The structure of the Global Location Number is shown in Table 7.

Table 7

Construction of GLN

\begin{tabular}{|c|c|c|}
\hline \multicolumn{3}{|c|}{ Global Location Number } \\
\hline GS1 company prefix (variable length) & Location reference number & Check digit \\
\hline \multicolumn{2}{|c|}{$\mathrm{N}_{1} \mathrm{~N}_{2} \mathrm{~N}_{3} \mathrm{~N}_{4} \mathrm{~N}_{5} \mathrm{~N}_{6} \mathrm{~N}_{7} \mathrm{~N}_{8} \mathrm{~N}_{9} \mathrm{~N}_{10} \mathrm{~N}_{11}$} & $\mathrm{~N}_{13}$ \\
\hline
\end{tabular}

Source: own study based on GALWAH (n.d.)

This code is most often used to designate storage locations in a warehouse, the destination to which a pallet should be delivered, or to identify the origin of a product. An additional extension can be added to the GLN to specify sublocations like dock gates or read / scan points. The extension is identified with the Application Identifier (254). This is necessary in the logging of supply chain events. It is also used in 
business transactions to refer to a buyer, seller, or shipping company. Thanks to the use of GLN, communication between trading partners is more effective. The administrator of the database of GLN locations is the GS1 National Organization.

Internal solutions may seem easier and simpler to implement, but there may be some problems with this, such as:

- duplication - business partners can use the same codes to identify their locations,

- complexity - the lack of a standard solution may result in different structures and formats, therefore creating an individual program tailored to our needs may turn out to be more complex and costly.

Using GLN provides the company with a method of identifying locations inside and outside the company and ensures that the codes are globally unique, which simplifies data processing and transmission (Date 2006, Śliwczyński et al. 2013). For this reason, they were used in the prototype of the product flow tracking system. For this purpose, the codes and the most important locations presented in Table 8 were adopted, which in the future can be extended to specific locations of the racks for storage in the warehouse.

Table 8

GLN codes adopted

\begin{tabular}{|c|c|}
\hline GLN code accepted & Location name \\
\hline 590123400001 & Reception magazine \\
\hline 590123400002 & Pre-production warehouse \\
\hline 590123400021 & Line 1 \\
\hline 590123400022 & Line 2 \\
\hline 590123400023 & Line 3 \\
\hline 590123400024 & Line 4 \\
\hline 590123400025 & Line 5 \\
\hline 590123400026 & Line 6 \\
\hline 590123400003 & Production \\
\hline 590123400031 & Line 1 \\
\hline 590123400032 & Line 2 \\
\hline 590123400033 & Line 3 \\
\hline 590123400034 & Line 4 \\
\hline 590123400035 & Line 5 \\
\hline 590123400036 & Line 6 \\
\hline 590123400004 & Finished products warehouse \\
\hline 590123400005 & Released \\
\hline
\end{tabular}

Source: own study based on GALWAH (n.d.) 
The "Issued" location means the gate of the Finished Products Warehouse through which their products are delivered to customers after the service has been performed. The scheme of the GLN code for Production Line 6 is shown in Figure 3.

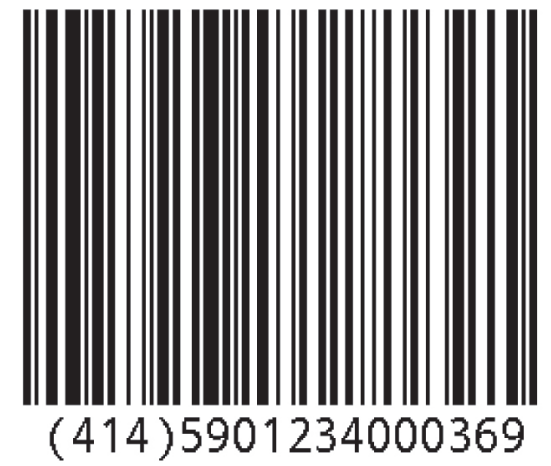

Fig. 3. GLN code of the Production Line 6 Source: own study based on GALWAH (n.d.)

\section{Development of an algorithm for product flow management with the use of bar codes}

To develop an algorithm for product flow management in the analyzed enterprise, an application called Tracker was built. It was created with the use of Ruby and the Rails (PostgreSQL 2021) development platform. The program is based on the Model-View-Controller design pattern, which is divided into three main parts:

- Model - logic representation,

- View - user interface,

- Controller - accepting input data from the user, responding to it with appropriate logic and updating views.

A set of tools was also used to facilitate the creation of the Bootstrap graphical interface (Biblioteka wkhtmltopdf, n.d.). One of the initial stages of implementation was to model a relational database, i.e., the way of data organization and the relations between them. Data is grouped into relationships which are sequentially combined into database schemas. In this case, there were relationships such as customers, products, orders, and the whole was combined into the Tracker database schema, as shown schematically in Figure 4.

One way to visually map a relationship is through a table. It must have a unique name and at least one attribute equated with the column. The column header, in addition to the attribute name, is to contain information about its representation, e.g., integers or a sequence of characters (strings). Moreover, the names of the attributes in one 
table cannot be repeated. Data is presented in the form of lines called tuples. Each relationship requires a primary key, marked as PM (primary key). It can be a single attribute or a combination thereof that will uniquely identify the data contained in each row of the table. Databases also have foreign keys that point to data from other tables, thus creating dependencies between them.

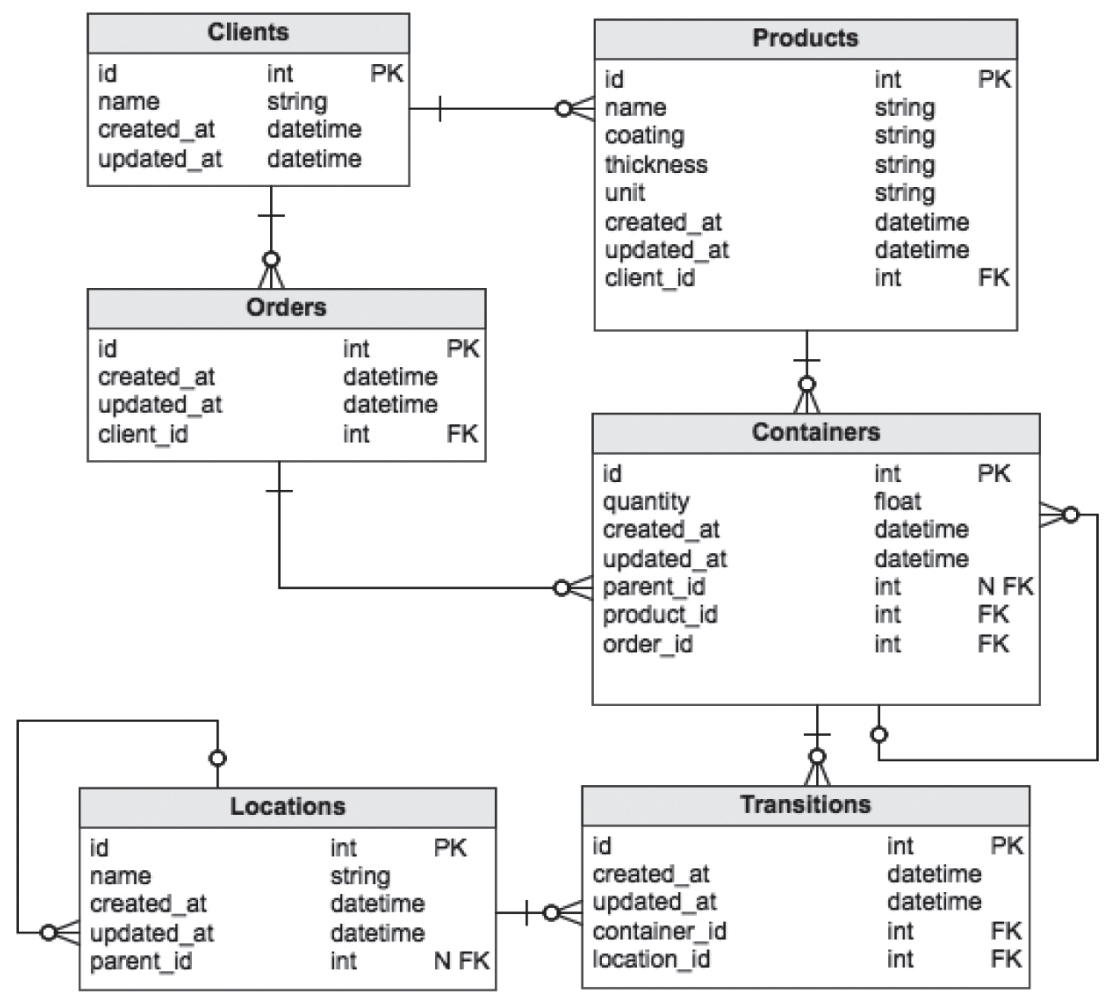

Fig. 4. Tracker database schema

Source: own study based on GALWAH (n.d.)

Searching and manipulating data in the model requires a query language, e.g. SQL, which is the most commonly used. Additionally, you need a database management system. In this project, PostgreSQL was chosen, which is a popular open-source system for managing relational databases. It works on most operating systems including Linux, UNIX, Mac OS X, and Windows. The main task of PostgreSQL as a database server is to securely store data and make it possible to extract it for queries from other applications. In this case, the Tracker program, written in Ruby, connects to the database server and executes SQL commands over the connection. The consumption relationships in the database are shown in Figure 5. 


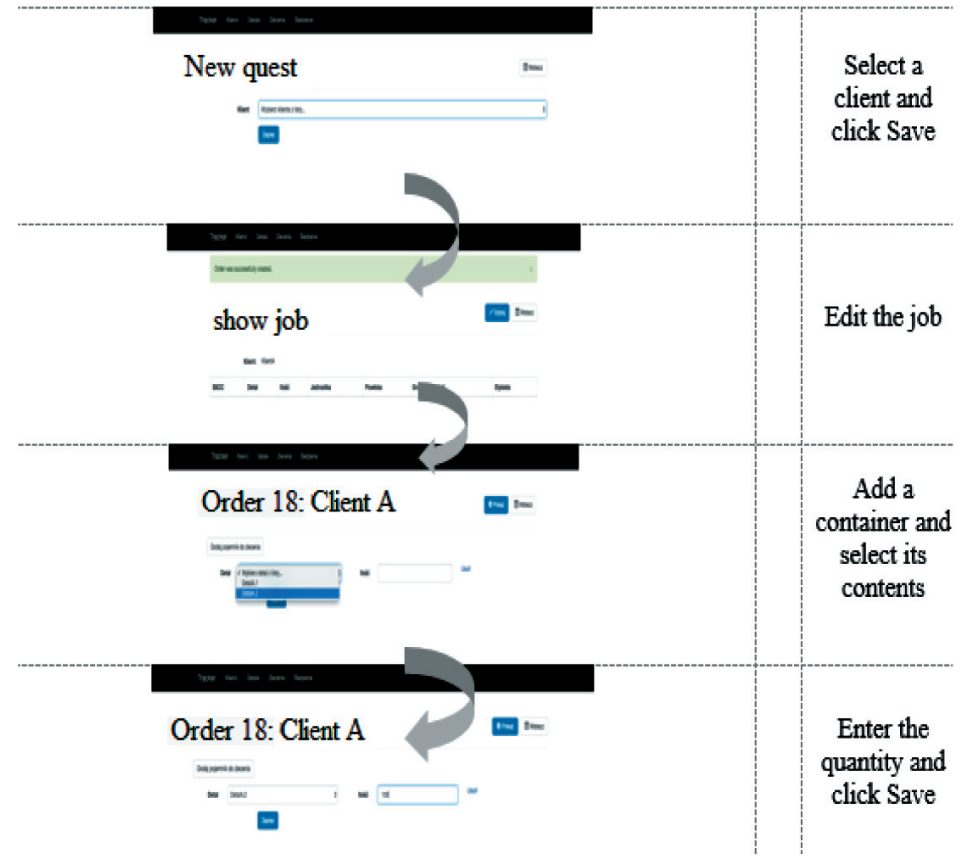

Fig. 5. Scheme for adding a new order to the database Source: own study based on GALWACH (n.d.)

Firstly, we select the client from the database. This corresponds to the connection between the clients and orders relations (Fig. 4), on the basis of which the name of the client can be placed in the drop-down list. When you click "Save", a new data row is created in the orders relation with: the new order identifier, time of saving and updating, and the identifier of the customer whose name we have chosen. In the next step, click, edit, and add a container to the orders, which corresponds to the combination of the orders and containers relations. Then the contents of the container are selected from the drop-down list. This list displays products assigned only to the customer whose order we are editing. This action is the result of linking containers, orders, clients, and products in that exact order.

Next, a number of details in the container are entered, which will correspond to the number attribute in the containers table. When you click Save, the following data will be automatically completed in the new data line: container identifier, time of saving and updating, parent_id (initially, as NULL, meaning nothing). Selected product and order identifiers will be assigned. Then, the first transition is also created for the container, the location of which will be set to the Receipt Warehouse.

Barcode generation is managed by using the open-source Zint library. The algorithm was implemented independently in the program, and on that basis it was possible 
to create SSCC and GTIN-14 codes. The SSCC consists of an extension digit, a country prefix, a coding unit code, padding with zeros, a container number, and a check digit. Padding with zeros to a constant length of 18 digits was performed by Line 16. A similar mechanism was used to determine the GTIN-14 code (Zint Barcode Generator, n.d.). The program also includes a preview of the container movement history. It was also supposed to bring benefits in the form of increasing traceability. Additionally, it could be a source of information about the production team responsible for deficiencies and complaints.

\section{Implementation in the enterprise and analysis of the results}

The company decided to test the operation of the system for production Line 6 due to the limited number of scanning devices. Assumptions for testing the prototype, Time: one shift -8 hours, Location: Reception Warehouse, Line 6 Pre-Production Warehouse, Production Line 6, Finished Goods Warehouse and the gate marking in the "Issued" system.

Equipment: 2 iPhone smartphones with the TrackerApp mobile application loaded, 1 computer in the Reception Warehouse with access to the Tracker application client, 1 laser printer, $2 \mathrm{WiFi}$ routers.

The test was to be carried out without major disruptions to the day-to-day operation of the plant. The study was to check the correctness of the implemented system and collect observations on the number of errors in labels, the speed of performed activities, and the benefits of the flow preview.

Before starting the study, the necessary barcodes for marking the location with the GLN code were generated and printed. A database of customers and details was also created, limited to those that were in the Reception Warehouse the day before or were to appear on the day of testing for Line 6 (specific type of electroplating). Just before the test, the printer was connected to the computer in the warehouse. Access to the local network was also provided for all devices. The test lasted one shift, i.e., 8 hours. Three additional people, duplicating the work of relevant employees, participated in it. This was to avoid disturbing the normal rhythm of work. Two labels were attached to the containers - the company's valid one and the test one. Person No. 1 accepted orders from the Reception Warehouse and added them via the Tracker application to the database, printed the labels and attached them to containers. Person No. 2 worked together with a warehouse worker responsible for the movement of containers between the Reception warehouse and the Pre-Production Warehouse of Line 6 as well as production on Line 6 and the warehouse of Finished Goods. They also handled the issue of products. Their responsibilities include scanning the containers and the 
destination code via the TrackerApp. Person No. 3 took the position of the operator of the production Line 6 and was responsible for receiving containers for production, with possible division, using the TrackerApp. The results of the implementation were positive, and the operation of the entire prototype did not raise any major concerns.

The results of the study are qualitative because they are subject to high randomness, and the key parameter is the human factor. Therefore, the analysis of the implementation results was made on the basis of observations. It can definitely be said that the assumptions of the project were met and the work of each system user could run faster. The elimination of redundancy has improved and among other things, the quality and speed of delivery. The data was entered once by the Sales Department, and thanks to this, an employee in the Warehouse does not have to enter them each time. All they have to do is to select the customer, the name of the detail, and enter the accepted number. The rest of the information was taken from the database and placed automatically on the label. Implemented drop-down lists of customers / details and the lack of the need to put other information (e.g. shell) at the same time eliminated label errors, which were the cause of up to (Biblioteka MTBBarcodeScanner, n.d.)

- looking for a missing container from the entire order, which was incorrectly marked with a different name of the content,

- looking for the cause, whether the error occurred while typing the name or when typing the shell (if someone realized that there was an error),

- performing an incorrect service.

Eliminating discrepancies gave a result consistent with the concept of Lean Production, i.e., minimizing unnecessary movements (searching) and eliminating errors in the production process.

The algorithm also shows that it is possible to instantly identify the places where containers are stored and, gives better access to information, and thus increases control and improves the production plan.

In addition, the permanently implemented algorithms will contribute to increasing the efficiency of the operators' work, as they would be focused only on the activities that need to be performed to complete the electroplating service. They will be less burdened by eliminating unnecessary steps such as manual rewriting of labels when dividing containers. Production preparation time would also be shortened.

No need to physically check the stage at which a given order is in favour of quick verification in the system and would increase customer satisfaction. The waiting time for a telephone inquiry about the possible date of receipt of the products would be limited to the few moments needed to check the information on the computer screen.

It would also be possible to quickly verify the time of acceptance of details for production and, in the event of a complaint, indicating its cause for production errors. 
Summing up, the results of the introduced solution were in line with expectations. The tool made it possible to track the flow of customer products in the researched service company, which significantly improved the internal logistics process. Users received clear information about the location, and the flow stage of a given reference, without having to physically check it. In addition, the time of many activities has been reduced, and the risk of confusion with labels has been minimized.

This confirmed the correct use of barcodes. In the event of developing this project, it could be extended with a module for providing clients with data on the progress of the service for individual orders and containers. This would probably translate into a higher level of customer service, competitiveness and an increase in demand for the company's services. Adding the estimated pickup time would make transportation planning easier for the company's customers. These modules could have a significant impact on the economic and commercial assessment (service level criterion) in the supplier qualification process.

Another possibility to extend the project would be to introduce a barcode-based inventory management solution. This could improve material needs planning. Additionally, it would be possible to link the average material consumption for a specific detail with the current order, which would allow forecasting the consumption and the level of stock in the following days.

\section{Conclusions}

The intensive development of commodity markets and the related need to process a large amount of information requires producers and traders to use modern data collection and transfer tools. The constantly increasing number of products in trade, as well as the growing requirements of today's consumers, make the effective functioning of the enterprise impossible without the support of information technology. Automatic identification systems using barcodes are described as such support. Nowadays, most goods produced have a barcode. Therefore, it is difficult to imagine selling products without using them. Moreover, after analyzing the problem, the following conclusions can be drawn:

1. The uniqueness of the codes identifying containers and goods on a global scale is ensured using SSCC and GTIN numbers, which are a standard developed by the GS1 organization.

2. Use GS1-128 code to record detailed information about container contents. The information about the product, its quantity, production batch recorded this way will be understandable by industrial scanners around the world, and the reader will receive the necessary information without having to access the company's database or contact its representatives. 
3. The use of a prototype to manage the flow of products and observation of the results helps to assess the legitimacy of investing in professional solutions. This is due to information with immeasurable effects related to the organization of the plant and the improvement of information flow.

4. Effective management and making quick and correct decisions requires access to up-to-date information about the processes taking place in the enterprise. It is possible thanks to the use of IT solutions with automatic data registration based on barcodes.

5. The best way to shorten the delivery acceptance time and reduce the occurrence of errors on logistics labels is to minimize the number of data entered into the system by the warehouse operatives, the use of drop-down lists and automatic completion of repeated information based on the database.

\section{References}

Biblioteka MTBBarcodeScanner, n.d., https://github.com/mikebuss/MTBBarcodeScanner [access: 13.05.2021].

Biblioteka wkhtmltopdf, n.d., https://github.com/wkhtmltopdf/wkhtmltopdf [access: 13.05.2021].

Date C.J., 2006, Relacyjne bazy danych dla praktyków, Helion, Gliwice.

Dębowski L., 2006, Technika RFID i jej aplikacje, Zeszyty Naukowe Wydziału Elektrotechniki i Automatyki Politechniki Gdańskiej, nr 22, pp. 31-36.

Długosz J., 2009, Nowoczesne technologie w logistyce, Polskie Wydawnictwo Ekonomiczne, Warszawa.

Fox M.N., 2021, Joseph Woodland, Inventor of the Bar Code, Dies At 91, The New York Times, http://www.nytimes.com/2012/12/13/business/n-joseph-woodland-inventorof-the-bar-code-dies-at-91.html?hp\&_r $=0$ [access: 13.05.2021].

GALWAH, n.d. [Załad Powłok Galwanicznych GALWACH's internal company materials, unpublished].

GS1 AISBL, 2021, GS1 General Specifications, wyd. 16, http://www.gs1.org/docs/barcodes/ GS1_General_Specifications.pdf [access: 13.05.2021].

Hałas E. (red. nauk.), 2012, Kody kreskowe i inne globalne standardy w biznesie, Biblioteka Logistyka, Instytut Logistyki i Magazynowania, Poznań.

Kwaśniowski S., Zając P., 2004, Automatyczna identyfikacja w systemach logistycznych, Oficyna Wydawnicza Politechniki Wrocławskiej, Wrocław.

Łazicki A., Krużycka L., Zieliński L., Jurek R., 2016, Zarządzanie magazynem, Wiedza i Praktyka, Warszawa.

Majewski J., 2006, Informatyka dla logistyki, Instytut Logistyki i Magazynowania, Poznań. 
Nelson B., 1997, Punched cards to bar codes: A 200 year journey with description of over 260 codes, Helmers Publishing Company, Peterborough, NH.

PN-ISO/IEC 15420:2007, 2007, Technologia informatyczna - Techniki automatycznej identyfikacji i gromadzenia danych - Wymagania dotyczące symboliki kodów kreskowych - EAN/UPC.

PostgreSQL, 2021, https://www.postgresql.org/about/ [access: 13.05.2021].

Radziejowska G., 2012, Aspekty logistyczne w zarządzaniu realizacja zamówień na przykładzie przedsiębiorstwa produkcyjnego, Zeszyty Naukowe, Organizacja i Zarządzanie/ Politechnika Śląska”, z. 60, pp. 305-320.

Śląski P., Giga A., 2005, Zarządzanie procesami logistycznymi w tańcuchu dostaw, Problemy Techniki i Uzbrojenia, R. 34, z. 95, pp. 19-24.

Śliwczyński B., Koliński A., Andrzejczyk P., 2013, Organizacja i monitorowanie procesów produkcyjnych, Instytut Logistyki i Magazynowania, Poznań.

Urban W., Ratter E., Wangwacharakul P., Poksinska B., 2018, Coexistence of the BRC Standard for Packaging and the Lean Manufacturing methodology, Engeneering Management in Production and Services, vol 10(3), pp. 51-61. https://doi.org/ 10.2478/emj-2018-0016.

Zint Barcode Generator, n.d., https://github.com/zint/zint [access: 13.05.2021].

Żyła R.J., 2021, Symbolika kodu EAN-8, http://zylla.wipos.p.lodz.pl/ut/barcode/ean8pl.html [access: 13.05.2021]. 